\title{
A Profile of Injuries Sustained by Law Enforcement Officers: A Critical Review
}

\author{
Kate Lyons ${ }^{1}$, Cameron Radburn ${ }^{1}$, Robin Orr ${ }^{1,2, *}$ and Rodney Pope ${ }^{1,2}$ \\ 1 Bond Institute of Health and Sport, Bond University, Gold Coast QLD 4229, Australia; \\ kate.lyons@student.bond.edu.au (K.L.); cameron.radburn@student.bond.edu.au (C.R.); \\ rpope@bond.edu.au (R.P.) \\ 2 Tactical Research Unit, Bond University, Gold Coast QLD 4229, Australia \\ * Correspondence: rorr@bond.edu.au \\ Academic Editor: Anthony R. Mawson \\ Received: 14 December 2016; Accepted: 24 January 2017; Published: 3 February 2017
}

\begin{abstract}
Due to the unpredictable, varied and often physical nature of law enforcement duties, police officers are at a high risk of work-related physical injury. The aim of this critical narrative review was to identify and synthesize key findings of studies that have investigated musculoskeletal injuries sustained by law enforcement officers during occupational tasks. A systematic search of four databases using key search terms was conducted to identify potentially relevant studies, which were assessed against key inclusion and exclusion criteria to determine studies to be included in the review. Included studies were critically appraised and the level of evidence determined. Relevant data were extracted, tabulated and synthesized. The 16 identified studies ranged in percentage quality scores from $25.00 \%$ to $65.00 \%$, with a mean score of $41.25 \%$ and high interrater agreement in scores reflected in a Cohen's Kappa coefficient, $k=0.977$. The most common body site of injury was the upper extremity, the most common injury types were soft-tissue sprains and strains and the most common cause of injury was a non-compliant offender, often involving assault. However, there was limited peer reviewed research in this area and the published research had a narrow focus and was of low to fair methodological quality.
\end{abstract}

Keywords: police; law enforcement; injury; tactical; occupational health

\section{Introduction}

Due to the unpredictable, varied, and physical nature of law enforcement, police officers are at a high risk of work-related physical injury [1]. The physical demands of law enforcement duties may include running varied distances with and without loads, restraining non-compliant offenders, carrying injured or unconscious people, self-defence manoeuvres, and manual handling tasks [2]. Sudden external forces when controlling a suspect or offender who is resisting arrest, trips and falls, and strains and sprains can all contribute to the high risk of injury within the law enforcement occupation [3].

As a result of these factors, law enforcement officers are at a greater risk of physical injury, specifically musculoskeletal injuries, than employees in many other occupations [3]. This greater injury risk has an impact not only on the worker, but also on the organization, which has to bear both the financial and workforce burdens of days lost due to injury and the post-injury rehabilitation or workers' compensation costs [4-7]. These costs vary greatly within the literature, depending on the severity of injury, the length of time off work and the country in which the study was completed. A recent study found that the estimated cost associated with an injured law enforcement employee varied from $\$ 2500$ to $\$ 12,000$ (USD), depending on the area injured [5]. Previous studies have speculated that changes 
to post-injury rehabilitation may be needed in an attempt to reduce the duration of time that law enforcement officers are off work and the associated financial burden [6].

By determining the current profile of sites, mechanisms and types of injuries sustained by law enforcement officers, informed rehabilitation practices and injury prevention strategies for officers can be developed. For example, by knowing the mechanism of an injury individualised programs to increase post injury resilience to these mechanism can be developed, which will enable better control of gradual loading and return to work conditioning. In addition, by knowing the mechanism of an injury, targeted injury prevention strategies, like pre-conditioning (e.g., strengthening exercises) [8] or other reduction methods (e.g., changing a floor surface) [9] can be applied. These approaches will in turn may have an impact on injury incidence and reducing injury severity [10]. Therefore, the aim of this critical narrative review was to identify, critically appraise and synthesize key findings from recent literature investigating musculoskeletal injuries in the law enforcement profession, in order to develop a profile of the injuries experienced by this unique population.

\section{Methods}

A two-tiered approach was used to identify studies of relevance to this review. First, a systematic search of key databases, using carefully-selected search terms, was completed on 16 September 2016. Search terms were identified through completing a rapid literature review testing different key words and examining the terms used in known research in this area. Once key words were identified, authors (K.L., C.R.) used the databases to compile the search phrases listed in Table 1.

Table 1. Details of literature search: databases used and search terms (completed on 16 September 2016).

\begin{tabular}{cc}
\hline Database & Search Terms \\
\hline PUBMED & (police OR law enforcement) AND (injury OR injuries) \\
\hline CINAHL & (police OR law enforcement) AND (injury OR injuries) \\
\hline EMBASE & ('police'/exp OR police OR 'law' / exp OR law \\
& AND enforcement) AND ('injury' / exp OR injury OR injuries) \\
\hline Ovid MEDLINE (@1946 to September Week 1 2016) & (police OR law enforcement) AND (injury OR injuries) \\
\hline
\end{tabular}

Secondly, additional studies of relevance from both peer-reviewed full-text sources and grey literature were sourced from known researchers in this field. Following removal of duplicates, all identified studies were then screened by title and abstract using pre-defined inclusion and exclusion criteria. Injury definitions varied across 5 of the included studies [6,11-14]. In the remaining studies injury was not defined. Considering this, for the purpose of this review, all studies which investigated law enforcement officers who were considered to have sustained 'an injury' were included. Several studies [7,13-17] did not specify whether the reported injuries occurred while the officer was on duty, whereas the remaining studies only included injuries that occurred whilst an officer was on duty $[5,6,11,12,15,18-22]$. The full criteria are detailed in Table 2. During the screening process, any studies which indicated potential to meet the eligibility criteria were obtained in full-text and reviewed in detail to determine final eligibility using the selection criteria.

To limit bias and to ensure objective selection of studies at the screening and full text selection stages, two reviewers separately screened and selected studies using the inclusion and exclusion criteria (K.L., C.R.). Any disagreements regarding which studies should move to the next stage were resolved by discussion and consensus.

Through this approach, search bias, duplication bias, inclusion criteria bias, and selector bias [23] were limited. The search terms were kept broad to be more inclusive of studies and to limit search bias; duplicates were removed as the first line of screening to limit duplication bias; and finally, to limit selector bias, two reviewers screened the abstracts and then selected full text studies for inclusion in the review. The inclusion and exclusion criteria were established prior to screening commencing. 
Table 2. Inclusion and exclusion criteria and examples of excluded studies.

\begin{tabular}{|c|c|}
\hline Inclusion Criteria & Example/s \\
\hline Study was focused on law enforcement officers & $\begin{array}{l}\text { Studies involving police officers, a police department, or a } \\
\text { police force }\end{array}$ \\
\hline $\begin{array}{l}\text { Study examined injuries occurring to, or in, a law } \\
\text { enforcement population }\end{array}$ & $\begin{array}{l}\text { Studies examining musculoskeletal injuries, } \\
\text { musculoskeletal disability, injury epidemiology, } \\
\text { injury rates, injury incidence }\end{array}$ \\
\hline Exclusion Criteria & Example/s \\
\hline $\begin{array}{l}\text { Study involved participants who were not general } \\
\text { Law Enforcement officers }\end{array}$ & Studies involving military police \\
\hline Study examined injuries caused by police officers & $\begin{array}{l}\text { Studies reporting police brutality, Taser injuries, excessive } \\
\text { use of force by police }\end{array}$ \\
\hline $\begin{array}{c}\text { Study included only injuries that were not } \\
\text { musculoskeletal injuries }\end{array}$ & $\begin{array}{l}\text { Studies which only examined fatalities, chemical hazards, } \\
\text { HIV, HEP B, Mortality, Homicide, Suicide, mental illness }\end{array}$ \\
\hline Study reported as an abstract only & \\
\hline
\end{tabular}

The included studies were critically appraised using a modified Downs and Black checklist. This checklist is designed to assess the methodological quality and provide a profile of study strengths and weaknesses for both randomized control trials and non-randomized studies [24,25]. This checklist utilizes twenty-seven questions to assess the methodological quality of studies and has been used in reviews involving tactical populations [24,26-29]. A modified version of this tool was used, with question 27, relating to statistical power, modified to award one point for a 'yes' answer, indicating the authors had reported a sample size or power analysis, or zero points for a 'no' answer, indicating they had not. This revised scoring approach for question 27 replaced the original 6-point scoring scale, ranging from zero to five points, and reduced the maximum possible raw score for the Downs and Black checklist to 28 , from the original 32 points [24]. This approach has been used previously in research due to subjectivity in the interpretation of the original question [25]. In addition to this modification, for the purposes of assessing methodological quality of studies included in the current review, several additional questions were ignored in the Down's and Black checklist (Q's 4, 8, 13, 14, $15,19,23 \& 24)$ [24], as they were designed to evaluate aspects of methodological quality that were specific to experimental studies rather than the epidemiological, observational research designs of the included studies. For example, checklist question 14 asks 'Was an attempt made to blind study subjects to the intervention they have received?'. The use of this additional modification to the Downs and Black checklist was not considered to have impacted on the analysis of study quality and meant that the included studies were not assessed against criteria for which they were never designed. This modification adjusted the maximum possible total raw score for the Downs and Black checklist to 20 points.

The critical appraisal of the included studies was completed individually by two authors (K.L., C.R.), with the level of interrater agreement on assigned scores then determined by a third author (R.O.) through calculation of a Cohen's kappa coefficient ( $\mathrm{k}$ ). This level of agreement was graded qualitatively, using previously published guidelines [30]. Following the Kappa analysis, any discrepancies in scores between the two primary raters were adjudicated by the third author (R.O.) to finalise the Critical Appraisal Scores (CAS). The qualitative ratings of methodological quality proposed by Kennelly [31] for specific ranges of total scores on the Downs and Black checklist were used to grade the studies. Due to the modifications made to the Downs and Black checklist, discussed above, all scores were first converted to percentages to enable grading using the approach of Kennelly [31]. On this basis, the grading criteria applied when rating the methodological quality of the included studies were as follows: Downs and Black total score $<45.4 \%$, 'poor' methodological quality; $45.4 \%-61.0 \%$, 'fair' methodological quality; and $>61.0 \%$, 'good' methodological quality.

Following critical appraisal of the included studies, key data were extracted and tabulated from all included studies by two authors (K.L., C.R.) independently and then compared, with any discrepancies 
resolved by discussion and consensus to arrive at the final tabulated data set. Data extracted and tabulated for each study included author/s, year of publication, title, aim, study design, level of evidence, injury definitions, participant details and main findings of relevance to the aims of this review. The level of evidence provided by each included study was graded using published Australian National Health and Medical Research Council (NHMRC) criteria [32]. These criteria range from Level I (systematic review of all randomized control trials, highest level of evidence available) to Level IV (evidence obtained from case series, less reliable level of evidence [32]. For studies that were unable to be graded using these criteria, a note was made in the relevant data table. The PRISMA (Preferred Reporting Items for Systematic Reviews and Meta-analyses) guidelines were also used to guide this review (see Figure 1) and the reporting of included studies [33].

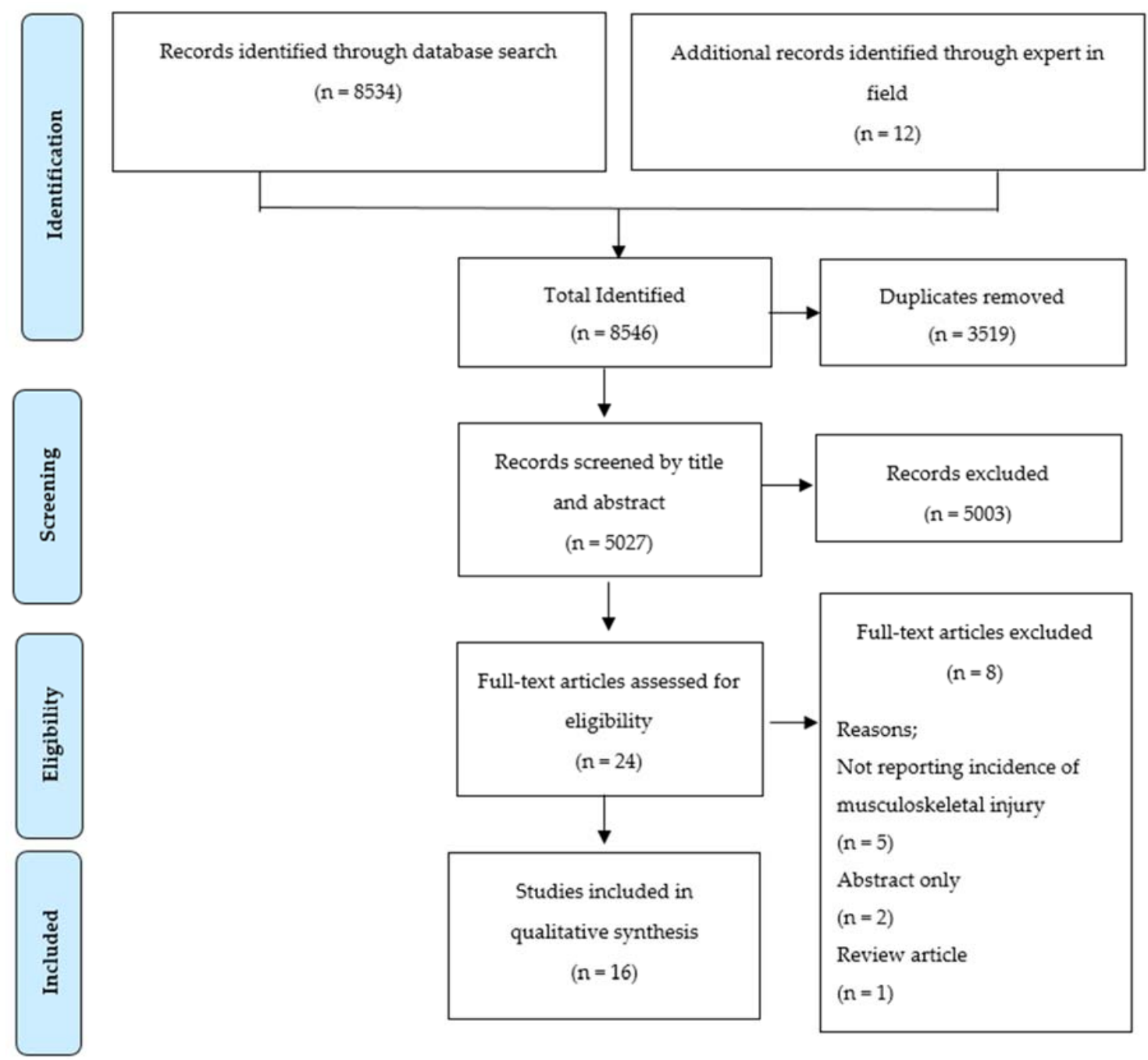

Figure 1. PRISMA flow diagram showing literature search, screening and eligibility results.

A critical narrative synthesis of key findings from the included studies was then conducted, with reference to the aims of the review, the tabulated data and further information provided in the original studies. In the synthesis, the findings from each included study were considered in the light of the respective study's methodological quality, represented by its CAS and Kennelly [31] quality rating. Injury incidence rates were calculated or transformed to be represented as number of injuries per 1000 personnel per year, based on the available data from each of the included studies, provided the required data were reported. This allowed for comparisons of the reported injury incidence rates between the studies included in this review and between studies reported in this review and 
studies of other tactical populations (e.g., fire fighters, military). Due to the variations across studies in reporting methods and classification systems for the sites, natures and mechanisms of injuries, reported categories for each of these injury data elements were re-coded into broader groups, guided by previous studies in tactical populations [34], in order to allow for valid comparisons.

\section{Results}

The database search results are reported in Table 3.

Table 3. Databases and search results prior to screening and removal of duplicates.

\begin{tabular}{cc}
\hline Database & Identified Studies $(\boldsymbol{n})$ \\
\hline PUBMED & 3845 \\
CINAHL & 634 \\
EMBASE & 1714 \\
Ovid MEDLINE (1946 to September Week 1 2016) & 2341 \\
\hline
\end{tabular}

The PRISMA flow diagram (Figure 1) provides an overview of the results of the literature search, screening and selection processes. In total the initial search identified 8534 publications with an additional 12 publications sourced through experts in the field. Following removal of duplicates, 5027 studies were reviewed by title and abstract for potential eligibility, resulting in 24 full text publications being retrieved and evaluated in detail for eligibility against the inclusion and exclusion criteria. In total, 16 publications were deemed eligible and retained to form the basis for this critical narrative review.

The results of the critical appraisals of the methodological quality of the included studies [31], using the modified Downs and Black checklist [24], are shown in Table A1 as raw scores. Questions from the checklist that were ignored as planned due to lack of relevance to the research designs of the included studies are left blank. The final percentage CAS indicating the methodological quality of each study is listed in Table 4, along with information regarding the study's aims, data sources, research designs, and the levels of evidence it provides. The Cohen's kappa analysis revealed an 'almost perfect agreement' between raters $(\mathrm{k}=0.977)$ [30] in the scores awarded to each study. One study was graded as being of 'good' methodological quality [15], seven studies were graded as being of 'fair' methodological quality $[7,14,16,19-21,26]$, and eight studies were graded as being of 'poor' methodological quality [5-18,22-25]. The mean ( \pm SD, Standard Deviation) percentage score for methodological quality of the included studies was $41.25 \%( \pm 10.08 \%)$, with a range of $25.00 \%[6,14]$ to $65.00 \%$ [15].

Common weaknesses were found across all included studies (see Table A1) in the areas of reporting (three of eight questions), external validity (one of two questions), internal validity-bias (two of four questions), and internal validity-confounding/selection bias (two of five questions). As noted in Table 4, of the 16 studies included in this review only two [12,22] were determined to constitute level II evidence, due to their use of a prospective cohort study design. The remaining 14 studies [4-7,11,13-21] were cross-sectional or retrospective cohort studies and were therefore deemed to constitute levels of evidence [32] ranging between III-2 and IV.

Of the included studies, 10 were conducted in the United States $[4,5,7,12,17-22]$, two in the United Kingdom [15,16], two in the Republic of Korea $[13,14]$ and one in each of the Islamic Republic of Iran [11] and Australia [6]. Table 5 provides details of each study's injury definition, participants and main findings. 
Table 4. Key information regarding the design, aims, data sources, critical appraisal score and levels of evidence of each included study.

\begin{tabular}{|c|c|c|c|c|c|c|}
\hline $\begin{array}{l}\text { Authors (Year) and } \\
\text { [Reference] }\end{array}$ & Title & Aim/Objective/Hypothesis & Study Design & Data Collection Method & Downs \& Black Score & Level of Evidence * \\
\hline Knapik et al. (2011) [12] & $\begin{array}{l}\text { Injury rates and injury risk } \\
\text { factors among federal bureau of } \\
\text { investigation new agent trainees }\end{array}$ & $\begin{array}{l}\text { To prospectively examine potential risk factors and } \\
\text { injury rates in a cohort of FBI new agents. }\end{array}$ & Prospective Cohort Study & Database & $65.00 \%$ & II \\
\hline Violanti et al. (2013) [7] & $\begin{array}{l}\text { Shift work and long-term injury } \\
\text { among police officers }\end{array}$ & $\begin{array}{l}\text { To determine whether the incidence of long-term injury } \\
\text { leave varies across shifts. }\end{array}$ & Cross-sectional Study & Point of care & $50.00 \%$ & IV \\
\hline Cho et al. (2014) [13] & $\begin{array}{l}\text { Factors Affecting the } \\
\text { Musculoskeletal Symptoms of } \\
\text { Korean Police Officers }\end{array}$ & $\begin{array}{l}\text { To investigate efficient, systematic management of the } \\
\text { Korean police and to examine the status and } \\
\text { prevention of musculoskeletal disorders in Korean } \\
\text { police officers. }\end{array}$ & $\begin{array}{l}\text { Cross-sectional } \\
\text { Questionnaire Study }\end{array}$ & Self-report & $50.00 \%$ & IV \\
\hline Boyce et al. (1992) [4] & $\begin{array}{l}\text { Workers' compensation claims } \\
\text { and physical fitness capacity of } \\
\text { police officers }\end{array}$ & $\begin{array}{l}\text { To compare level of physical fitness with workers' } \\
\text { compensation claims among } 514 \text { police officers. }\end{array}$ & Cross-sectional Study & Point of care & $50.00 \%$ & IV \\
\hline Superko et al. (1988) [17] & $\begin{array}{l}\text { Effects of a Mandatory Health } \\
\text { Screening and Physical } \\
\text { Maintenance Program for Law } \\
\text { Enforcement Officers }\end{array}$ & $\begin{array}{l}\text { To present findings regarding the effects of a } \\
\text { mandatory health assessment, physical performance } \\
\text { testing, and disease prevention program used by the } \\
\text { California Highway Patrol. }\end{array}$ & $\begin{array}{l}\text { Retrospective Cohort Study } \\
\text { (Pre-Post Intervention Study } \\
\text { using two retrospective cohorts) }\end{array}$ & Database & $45.00 \%$ & IV \\
\hline Gyi et al. (1998) [15] & $\begin{array}{l}\text { Musculoskeletal problems and } \\
\text { driving in police officers }\end{array}$ & $\begin{array}{l}\text { To examine the effect of driving on sickness absence } \\
\text { and prevalence data for musculoskeletal troubles of } \\
\text { police officers. }\end{array}$ & $\begin{array}{l}\text { Cross-sectional } \\
\text { Questionnaire Study }\end{array}$ & Self-report & $45.00 \%$ & IV \\
\hline Burton et al. (1996) [16] & $\begin{array}{l}\text { Occupational risk factors for the } \\
\text { first-onset and subsequent } \\
\text { course of low back trouble: } \\
\text { a study of serving police officers }\end{array}$ & $\begin{array}{l}\text { To determine the hazard for first-onset and subsequent } \\
\text { course of low back trouble associated with } \\
\text { occupational physical and psychosocial stressors. }\end{array}$ & $\begin{array}{l}\text { Cross-sectional } \\
\text { Questionnaire Study }\end{array}$ & Self-report & $45.00 \%$ & IV \\
\hline Sullivan et al. (1988) [22] & $\begin{array}{l}\text { Epidemiological studies of } \\
\text { work-related injuries among } \\
\text { law enforcement personnel }\end{array}$ & $\begin{array}{l}\text { To calculate the work-related injury only rates for } \\
\text { employees working in different assignments; to see if } \\
\text { there were sex or age differences in injury rates for } \\
\text { workers performing similar assignments; to learn how } \\
\text { the injuries occurred; and to examine the impact of } \\
\text { these injuries in terms of days lost from work and } \\
\text { claim costs. }\end{array}$ & $\begin{array}{l}\text { (1) Cross-sectional descriptive } \\
\text { study with 'nested'/linked: } \\
\text { (2) retrospective cohort } \\
\text { study; and } \\
\text { (3) prospective cohort } \\
\text { study components }\end{array}$ & Database & $45.00 \%$ & $\begin{array}{l}\text { (1) IV } \\
\text { (2) III-2 } \\
\text { (3) II }\end{array}$ \\
\hline Jahani et al. (2002) [11] & $\begin{array}{l}\text { Musculoskeletal disabilities } \\
\text { among police force personnel of } \\
\text { the Islamic Republic of Iran }\end{array}$ & $\begin{array}{l}\text { To assess the frequency of musculoskeletal disabilities } \\
\text { in police force personnel and to determine the } \\
\text { association between disabilities and age, rank, and } \\
\text { different job types. }\end{array}$ & Retrospective Cohort Study & Database & $40.00 \%$ & III-2 \\
\hline
\end{tabular}


Table 4. Cont.

\begin{tabular}{|c|c|c|c|c|c|c|}
\hline $\begin{array}{l}\text { Authors (Year) and } \\
\text { [Reference] }\end{array}$ & Title & Aim/Objective/Hypothesis & Study Design & Data Collection Method & Downs \& Black Score & Level of Evidence * \\
\hline $\begin{array}{l}\text { Holloway-Beth et al. } \\
\text { (2016) [5] }\end{array}$ & $\begin{array}{l}\text { Occupational Injury } \\
\text { Surveillance Among Law } \\
\text { Enforcement Officers Using } \\
\text { Workers' Compensation Data, } \\
\text { Illinois } 1980 \text { to } 2008\end{array}$ & $\begin{array}{l}\text { To use Illinois Workers' Compensation Commission } \\
\text { data to (1) determine the annual and cumulative claim } \\
\text { rates for injuries suffered by law enforcement } \\
\text { personnel; (2) describe the causes and nature of } \\
\text { occupational injuries suffered by the four major groups } \\
\text { of law enforcement officers; and (3) evaluate three } \\
\text { important workers' compensation outcomes related to } \\
\text { long-term impacts of on-the-job injury or illness. }\end{array}$ & Retrospective Cohort Study & Database & $40.00 \%$ & III-2 \\
\hline Nabeel et al. (2007) [20] & $\begin{array}{l}\text { Correlation between physical } \\
\text { activity, fitness, and } \\
\text { musculoskeletal injuries in } \\
\text { police officers }\end{array}$ & $\begin{array}{l}\text { To explore whether Minneapolis police officers who } \\
\text { had higher levels of fitness and physical activity has } \\
\text { fewer musculoskeletal injuries than those who were } \\
\text { not as active or fit. }\end{array}$ & $\begin{array}{l}\text { Cross-sectional } \\
\text { Questionnaire Study }\end{array}$ & Self-report & $35.00 \%$ & IV \\
\hline Reichard et al. (2010) [19] & $\begin{array}{l}\text { Occupational injuries among } \\
\text { emergency responders }\end{array}$ & $\begin{array}{l}\text { To address the limited availability of nonfatal injury } \\
\text { information for Emergency Medical Services personnel, } \\
\text { fire fighters, and police (herein grouped as emergency } \\
\text { responders) and the lack of comparable data, the } \\
\text { authors analysed occupational injuries and illnesses } \\
\text { among these workers which were treated in U.S. } \\
\text { hospital emergency departments 2000-2001. }\end{array}$ & Retrospective Cohort Study & Database & $35.00 \%$ & III-2 \\
\hline Brandl et al. (2012) [18] & $\begin{array}{l}\text { The Physical Hazards of Police } \\
\text { Work Revisited }\end{array}$ & $\begin{array}{l}\text { To examine the extent to which injuries to police } \\
\text { officers have changed from 1996-1998 to 2006-2008. }\end{array}$ & Retrospective Cohort Study & Database & $35.00 \%$ & III-2 \\
\hline Brandl et al. (2003) [21] & $\begin{array}{l}\text { Toward an Understanding of } \\
\text { the Physical Hazards of } \\
\text { Police Work }\end{array}$ & $\begin{array}{l}\text { To analyze the nature and frequency of police injuries } \\
\text { sustained either by accident or assault for police } \\
\text { officers and comparing these to injuries sustained by } \\
\text { fire fighters to develop a more complete appreciation of } \\
\text { the relative hazards of police work. }\end{array}$ & Retrospective Cohort Study & Database & $30.00 \%$ & III-2 \\
\hline Larsen et al. (2016) [6] & $\begin{array}{l}\text { The Injury Profile of an } \\
\text { Australian Specialist } \\
\text { Policing Unit }\end{array}$ & $\begin{array}{l}\text { To quantify the number of isolated versus multiple } \\
\text { injuries in the force and to investigate the associated } \\
\text { costs and time away from work following } \\
\text { work-related injury. }\end{array}$ & Retrospective Cohort Study & Database & $25.00 \%$ & III-2 \\
\hline Rhee et al. (2015) [14] & $\begin{array}{l}\text { Prevalence of Musculoskeletal } \\
\text { Disorders Among Korean } \\
\text { Police Personnel }\end{array}$ & $\begin{array}{l}\text { To investigate efficient, systematic management of the } \\
\text { Korean police and to examine the status and } \\
\text { prevention of musculoskeletal disorders in Korean } \\
\text { police officers. }\end{array}$ & Retrospective Cohort Study & Database & $25.00 \%$ & III-2 \\
\hline
\end{tabular}

${ }^{*}$ NHMRC guidelines used to determine the level of evidence [32] 
Table 5. Injury definitions, participants and main findings from each included study.

\begin{tabular}{|c|c|c|c|c|}
\hline $\begin{array}{l}\text { Authors (Year) and } \\
\text { [Reference] }\end{array}$ & Title & Injury Definition & Participant Details & Main Findings \\
\hline Knapik et al. (2011) [12] & $\begin{array}{l}\text { Injury rates and injury risk } \\
\text { factors among federal bureau of } \\
\text { investigation new agent } \\
\text { trainees }\end{array}$ & $\begin{array}{l}\text { An injury case was defined as a new } \\
\text { agent who sustained physical } \\
\text { damage to the body and sought } \\
\text { medical care or medical } \\
\text { compensation one or more times } \\
\text { during the Federal Bureau of } \\
\text { Investigation (FBI) new agent } \\
\text { training course. }\end{array}$ & $\begin{array}{l}\text { FBI new agents }(n=531) \\
\text { Males }(n=426) \\
24.4-29.9 \text { years }(n=188) \\
\text { 30.0-38.6 years }(n=238) \\
\text { Females }(n=105) \\
\text { 24.1-29.9 years }(n=60) \\
30.0-37.0 \text { years }(n=45)\end{array}$ & $\begin{array}{l}\text { One or more injuries during FBI academy } \\
\text { training was recorded for } 35 \% \text { of men and } \\
42 \% \text { of women. } \\
\text { Defensive tactics training accounted for } \\
\text { the highest number of total injuries at } 58 \% \text {. } \\
\text { For both male and female injury risk was } \\
\text { increased with slower } 300 \text { m sprint, } \\
1.5 \text { mile run, and lower points on the } \\
\text { physical fitness test. } \\
\text { In males, increased age was also a } \\
\text { significant risk factor for injury. } \\
590 \text { injuries per } 1000 \text { personnel, per year. }\end{array}$ \\
\hline Violanti et al. (2013) [7] & $\begin{array}{l}\text { Shift work and long-term injury } \\
\text { among police officers }\end{array}$ & No Injury definition & $\begin{array}{l}\text { Police officers from the Buffalo Police } \\
\text { Department }(n=419) \\
\text { Males }(n=312) \\
\text { Females }(n=107) \\
\text { Average age } 43 \text { years old }\end{array}$ & $\begin{array}{l}\text { Night shift had the highest incidence of } \\
\text { long-term injuries }>90 \text { days compared to } \\
\text { afternoon and day shifts. } \\
\text { Officers on night shift also had a greater } \\
\text { risk of long-term injury compared to } \\
\text { short-term. } \\
\text { Incidence rate per } 100,000 \text { person hours: } \\
\text { Day shift: } 0.48 \\
\text { Afternoon shift: } 0.59 \\
\text { Night shift: } 1.33\end{array}$ \\
\hline Cho et al. (2014) [13] & $\begin{array}{l}\text { Factors Affecting the } \\
\text { Musculoskeletal Symptoms of } \\
\text { Korean Police Officers }\end{array}$ & $\begin{array}{l}\text { Definition of musculoskeletal } \\
\text { disorders is damage to } \\
\text { nerves/muscles in the neck, } \\
\text { shoulder, waist, arm/leg, and } \\
\text { surrounding body tissues caused by } \\
\text { repetitive motion, inappropriate } \\
\text { position, use of excessive force, } \\
\text { physical contact with sharp surfaces, } \\
\text { vibration, temperature, etc. }\end{array}$ & $\begin{array}{l}\text { Police officers }(n=353) \\
\text { All male }(100 \%) \\
\text { Mean age }(\text { Standard Deviation }[S D])=52.92 \\
(8.71) \text { years old }\end{array}$ & $\begin{array}{l}\text { Area of injury and prevalence: } \\
\text { Shoulder }(44.2 \%) \\
\text { Waist }(41.4 \%) \\
\text { Neck/head }(31.2 \%) \\
\text { Legs/foot }(26.1 \%) \\
\text { Hand/wrist/finger }(16.7 \%) \\
\text { Arm/elbow }(14.7 \%) \\
2500 \text { injuries, per } 1000 \text { personnel, per year. }\end{array}$ \\
\hline
\end{tabular}


Table 5. Cont.

\begin{tabular}{|c|c|c|c|c|}
\hline $\begin{array}{l}\text { Authors (Year) and } \\
\text { [Reference] }\end{array}$ & Title & Injury Definition & Participant Details & Main Findings \\
\hline Boyce et al. (1992) [4] & $\begin{array}{l}\text { Workers' compensation claims } \\
\text { and physical fitness capacity of } \\
\text { police officers }\end{array}$ & No Injury definition & $\begin{array}{l}\text { Police officers }(n=514) \text { : } \\
\text { Collected workers compensation }(n=124) \\
\text { Males }(n=96) \\
\text { Mean age }(\mathrm{SD})=33(7.3) \text { years old } \\
\text { Females }(n=30) \\
\text { Mean age }(\mathrm{SD})=30.3(5.3) \text { years old } \\
\text { Didn't collect workers compensation }(n=390) \\
\text { Males }(n=340) \\
\text { Mean age }(\mathrm{SD})=36.3(8.4) \text { years old } \\
\text { Females }(n=48) \\
\text { Mean age }(\mathrm{SD})=30.2(5.9) \text { years old }\end{array}$ & $\begin{array}{l}\text { Significantly more females collected } \\
\text { workers' compensation payments than } \\
\text { males }(p<0.002) \\
\text { Officers with the rank of sergeant or } \\
\text { higher had significantly lower rates of } \\
\text { claims for workers' compensation } \\
\text { ( } p<0.001) \\
\text { Of the males that did collect workers } \\
\text { compensation they were significantly } \\
\text { younger }(p<0.001) \\
\text { The lowest workers compensation claims } \\
\text { came from those who were either in the } \\
\text { highest or lowest fitness level. } \\
240 \text { injuries, per } 1000 \text { personnel, per year. }\end{array}$ \\
\hline Superko et al. (1988) [17] & $\begin{array}{l}\text { Effects of a Mandatory Health } \\
\text { Screening and Physical } \\
\text { Maintenance Program for Law } \\
\text { Enforcement Officers }\end{array}$ & No Injury definition & $\begin{array}{l}\text { California Highway Patrol Officers } \\
\text { Baseline testing }(n=4480) \\
98.2 \% \text { male } \\
1.8 \% \text { female }\end{array}$ & $\begin{array}{l}\text { Medical referrals and Job actions } \\
\text { Significant decreases in annual sick days, } \\
\text { job-related injuries and cost of injuries } \\
(p<0.001) \\
\text { Body fat and Injuries } \\
\text { Uninjured officers had a significantly } \\
\text { lower percentage of body fat than those } \\
\text { injured }(p<0.001) \\
\text { Injury rates not reported. }\end{array}$ \\
\hline Gyi et al. (1998) [15] & $\begin{array}{l}\text { Musculoskeletal problems and } \\
\text { driving in police officers }\end{array}$ & No Injury definition & $\begin{array}{l}\text { Study Group }(n=80) \\
\text { Traffic control officers } \\
\text { Males }(n=79) \\
\text { Females }(n=1) \\
\text { Mean age }(\mathrm{SD})=37.65(7.7) \text { years old } \\
\text { Control Group }(n=91) \\
\text { General duty officers } \\
\text { Males }(n=87) \\
\text { Females }(n=4) \\
\text { Mean age }(\mathrm{SD})=36.76(9.11) \text { years old }\end{array}$ & $\begin{array}{l}\text { Lower back was the most frequently } \\
\text { reported area of discomfort for traffic } \\
\text { control officers driving cars at } 35 \% \text { of } \\
\text { all injuries. } \\
\text { The mean prevalence of lower back } \\
\text { conditions was } 28 \% \text { for the study and } \\
\text { control groups. } \\
\text { Over } 12 \text { months, traffic control officers } \\
\text { had a higher incidence of }>8 \text { days missed } \\
\text { due to lower back trouble when compared } \\
\text { with the control. } \\
710 \text { injuries, per } 1000 \text { personnel, per year. }\end{array}$ \\
\hline
\end{tabular}


Table 5. Cont

\begin{tabular}{|c|c|c|c|c|}
\hline $\begin{array}{l}\text { Authors (Year) and } \\
\text { [Reference] }\end{array}$ & Title & Injury Definition & Participant Details & Main Findings \\
\hline Burton et al. (1996) [16] & $\begin{array}{l}\text { Occupational risk factors for the } \\
\text { first-onset and subsequent } \\
\text { course of low back trouble: a } \\
\text { study of serving police officers }\end{array}$ & No Injury definition & $\begin{array}{l}\text { Police officers }(n=1885) \\
\text { Royal Ulster Constabulary (exposed to heavy } \\
\text { body armour) officers }(n=1508) \\
\text { Male }(92 \%) \\
\text { Female }(8 \%) \\
\text { Mean age }(\text { SD) }=38.3(8.8) \text { years old } \\
\text { Greater Manchester Police officers } \\
(n=377) \\
\text { Male }(87 \%) \\
\text { Female }(13 \%) \\
\text { Mean age }(\mathrm{SD})=37.5(7.2) \text { years old }\end{array}$ & $\begin{array}{l}\text { Those who were exposed to either } \\
\text { vibration or increased time wearing heavy } \\
\text { body armour had an increased injury } \\
\text { incidence rate. However no injury rates } \\
\text { were reported. }\end{array}$ \\
\hline Sullivan et al. (1988) [22] & $\begin{array}{l}\text { Epidemiological studies of } \\
\text { work-related injuries among } \\
\text { law enforcement personnel }\end{array}$ & No Injury definition & $\begin{array}{l}\text { Los Angeles County Sheriff's } \\
\text { Department Employees } \\
\text { Descriptive } \\
\text { Injury claims }(n=2167) \\
\text { RetrospectiveWorkers' compensation claims } \\
(n=417) \\
\text { Prospective } \\
\text { Claims followed until close or up to } 2 \text { years } \\
(n=261)\end{array}$ & $\begin{array}{l}\text { Descriptive } \\
\text { No difference in injury rates } \\
\text { between gender } \\
30-34 \text { age group showed the highest } \\
\text { incidence of injury } \\
27 \text { injuries, per } 100 \text { employees, per year } \\
\text { Retrospective } \\
\text { Wrist/hand }(n=61) \text {, back }(n=42) \text { and } \\
\text { knee }(n=27) \text { were the three most common } \\
\text { areas of injury } \\
38 \% \text { of back injuries were repeat injuries } \\
\text { Overexertion was significantly linked with } \\
\text { new back injuries ( } p<0.005) \\
\text { Prospective } \\
\text { Back injuries caused the most days off full } \\
\text { duty and cost more than all other injuries } \\
2380 \text { injuries, per } 1000 \text { personnel, per year }\end{array}$ \\
\hline
\end{tabular}


Table 5. Cont

\begin{tabular}{|c|c|c|c|c|}
\hline $\begin{array}{l}\text { Authors (Year) and } \\
\text { [Reference] }\end{array}$ & Title & Injury Definition & Participant Details & Main Findings \\
\hline Jahani at al. (2002) [11] & $\begin{array}{l}\text { Musculoskeletal disabilities } \\
\text { among police force personnel of } \\
\text { the Islamic Republic of Iran }\end{array}$ & $\begin{array}{l}\text { Musculoskeletal disease cases were } \\
\text { defined as any case of disabilities in } \\
\text { which the diagnosis was in domain } \\
\text { of musculoskeletal diseases, } \\
\text { including skeletal/joint } \\
\text { impairments or limitation of motion, } \\
\text { muscle injuries, peripheral nerve } \\
\text { neuritis or neuralgia in upper and } \\
\text { lower extremities, neck and trunk. }\end{array}$ & $\begin{array}{l}\text { Police force personnel musculoskeletal } \\
\text { disability cases }(n=669) \\
\text { Mean age }(\mathrm{SD})=38.7(7.5) \text { years old }\end{array}$ & $\begin{array}{l}\text { Musculoskeletal disorders accounted for } \\
25.7 \% \text { of all physical disability in the } \\
\text { police force personnel. } \\
\text { Back disorders accounted for } 43.6 \% \text { of } \\
\text { total musculoskeletal disorders. } \\
\text { Commissioned officers had the highest } \\
\text { number of back disorders compared to } \\
\text { non-commissioned officers }(p<0.0001) \\
\text { Non-commissioned officers had higher } \\
\text { numbers of dislocations and fractures } \\
\text { compared to commissioned }(p<0.001)\end{array}$ \\
\hline $\begin{array}{l}\text { Holloway-Beth et al. } \\
\text { (2016) [5] }\end{array}$ & $\begin{array}{l}\text { Occupational Injury } \\
\text { Surveillance Among Law } \\
\text { Enforcement Officers Using } \\
\text { Workers' Compensation Data, } \\
\text { Illinois } 1980 \text { to } 2008\end{array}$ & No Injury definition & $\begin{array}{l}\text { Law enforcement personnel claims } \\
(n=18,892) \\
45 \% \text { Correctional institutions } \\
\text { Mean age }(\mathrm{SD})=37.5(10) \\
26 \% \text { Municipal police } \\
\text { Mean age }(\mathrm{SD})=37.2(8.9) \\
22 \% \text { Sheriff's department } \\
\text { Mean age }(\mathrm{SD})=39.7(10.3) \\
7 \% \text { State police } \\
\text { Mean age }(\mathrm{SD})=38.9(8.9)\end{array}$ & $\begin{array}{l}\text { Upper extremity was the most common } \\
\text { body part affected ( }>26 \% \text { in all } \\
\text { law enforcement) } \\
\text { Correctional officers had the highest } \\
\text { number of injuries, but the lowest severity }\end{array}$ \\
\hline Reichard et al. (2010) [19] & $\begin{array}{l}\text { Occupational injuries among } \\
\text { emergency responders }\end{array}$ & No Injury definition & $\begin{array}{l}\text { Emergency responders work-related injuries } \\
(n=123,900) \\
\text { Of this } 52 \% \text { was Law enforcement officer } \\
\text { work-related injuries }(n=64,800) \\
\text { Male }(87 \%) \\
\text { Female }(13 \%) \\
<25 \text { years old }(n=3000) \\
25-34 \text { years old }(n=34,200) \\
\text { 35-44 years old }(n=18,100) \\
>44 \text { years old }(n=9500)\end{array}$ & $\begin{array}{l}34 \% \text { of law enforcement injuries were } \\
\text { sprains/strains } \\
\text { Law enforcement injuries, top } 4 \\
\text { injury areas; } \\
26 \% \text { were to the leg and foot } \\
19 \% \text { were to the hand } \\
17 \% \text { were to the neck \& back } \\
17 \% \text { were to the arm }\end{array}$ \\
\hline
\end{tabular}


Table 5. Cont

\begin{tabular}{|c|c|c|c|c|}
\hline $\begin{array}{l}\text { Authors (Year) and } \\
\text { [Reference] }\end{array}$ & Title & Injury Definition & Participant Details & Main Findings \\
\hline Brandl et al. (2012) [18] & $\begin{array}{l}\text { The Physical Hazards of Police } \\
\text { Work Revisited }\end{array}$ & No Injury definition & $\begin{array}{l}\text { Milwaukee Police Department officer } \\
1996-1998 \text { officers }(n=1713) \\
\text { Total injuries }(n=2867) \\
\text { 2006-2208 officers }(n=1604) \\
\text { Total injuries }(n=2112)\end{array}$ & $\begin{array}{l}\text { 1996-1998 } \\
\text { Sprain/strain }(17.1 \%) \\
\text { Other muscle pain }(17.2 \%) \\
\text { Occurred controlling/arresting } \\
\text { subject }(42.9 \%) \\
2006-2008 \\
\text { Sprain/strain }(22.7 \%) \\
\text { Other muscle pain }(20.2 \%) \\
\text { Occurred controlling/arresting } \\
\text { subject (38.5\%) } \\
480 \text { injuries, per } 1000 \text { personnel, per year. }\end{array}$ \\
\hline Brandl et al. (2003) [21] & $\begin{array}{l}\text { Toward an Understanding of } \\
\text { the Physical Hazards of } \\
\text { Police Work }\end{array}$ & No Injury definition & $\begin{array}{l}\text { Patrol officers/detectives }(n=1700) \\
\text { Police injury reports }(n=1054)\end{array}$ & $\begin{array}{l}\text { Sprain/strain }(18.9 \%) \\
\text { Other muscle pain }(15.6 \%) \\
\text { Occurred controlling/arresting } \\
\text { subject }(43.8 \%) \\
\text { Medical attention sought }(50.8 \%) \\
\text { Time off work }(13.3 \%) \\
\text { Rate of injury incidents per officer }=0.610 \text {. } \\
530 \text { injuries, per } 1000 \text { personnel, per year. }\end{array}$ \\
\hline Larsen et al. (2016) [6] & $\begin{array}{l}\text { The Injury Profile of an } \\
\text { Australian Specialist } \\
\text { Policing Unit }\end{array}$ & $\begin{array}{l}\text { Injury was defined as any mild } \\
\text { physical harm (e.g., bruises), or any } \\
\text { major physical harm involving } \\
\text { outpatient or inpatient treatment }\end{array}$ & Police officers $(n=170)$ & $\begin{array}{l}\text { Injured officers }(n=138) \\
\text { Total injuries }(n=229) \\
\text { Injuries per employee }(n=2.57) \\
\text { Isolated injuries }(34.9 \%) \\
\text { Multiple injuries }(65.1 \%) \\
\text { Occurred during operational policing } \\
\text { duty }(48.9 \%) \\
\text { Attributed to non-compliant } \\
\text { offender }(31.4 \%) \\
\text { Sprain/Strain }(61.1 \%) \\
\text { Top } 3 \text { injury areas; } \\
\text { Hand/wrist }(21 \%) \\
\text { Back }(16.6 \%) \\
\text { Head/neck }(16.2 \%) \\
410 \text { injuries, per } 1000 \text { personnel, per year. }\end{array}$ \\
\hline Rhee et al. (2015) [14] & $\begin{array}{l}\text { Prevalence of Musculoskeletal } \\
\text { Disorders Among Korean } \\
\text { Police Personnel }\end{array}$ & $\begin{array}{l}\text { Health disorders that occur in the } \\
\text { neck, shoulder, waist, and upper } \\
\text { and lower extremities, and adjacent } \\
\text { tissues by hazardous factors such as } \\
\text { repetitive motion. }\end{array}$ & $\begin{array}{l}\text { Police officers who visited the Seoul } \\
\text { police hospital } \\
2009(n=40,963) \\
2010(n=48,184)\end{array}$ & $\begin{array}{l}\text { X-ray, Computed Tomography }(\mathrm{CT}) \text { and } \\
\text { MRI scans were most common for lower } \\
\text { extremity and spine disorders }(p<0.05) \\
\text { Knee and lumbar examinations were the } \\
\text { most frequent }(p<0.05)\end{array}$ \\
\hline
\end{tabular}

BMI = Body Mass Index: CI = Confidence Interval: CT = Computed Tomography: FBI = Federal Bureau of Investigation: MRI = Magnetic resonance imaging: SD = Standard Deviation. 
Injuries associated with different law enforcement occupational tasks were reported by seven of the studies $[5,6,12,18,19,21,22]$. There were varying ways that researchers gathered their injury data (Table 4). Five studies $[4,5,18,21,22]$ collected data from workers' compensation claims or reports, and three $[13,14,19]$ collected their data from facilities to which law enforcement personnel presented with their injuries, e.g., hospitals. The remaining studies $[7,11,12,20]$ gathered their data from law enforcement injury records filed by individual police departments or from surveys given to law enforcement personnel. For the one study [19] which collected data on emergency services personnel, only law enforcement officer data was extracted and used in this review. The observed injury incidence rates were calculable using data from nine of the included studies $[4,6,12,13,15,18,20-22]$ (Figure 2). The reported incidence of injury for law enforcement personnel included in the studies reviewed varied from 240 [4] to 2500 [13] per 1000 personnel per annum, with no clear patterns evident based on particular population types or other contextual factors, for example injury reporting processes. Of the 16 included studies, only five [6,11-14] provided a clear definition of injury, with most only reporting the type of injury they were investigating, without providing a more comprehensive definition of exactly what comprised those types. This lack of clear injury definitions in most included studies prevented valid comparison of injury rates between studies and between the varying populations and contexts associated with the studies.

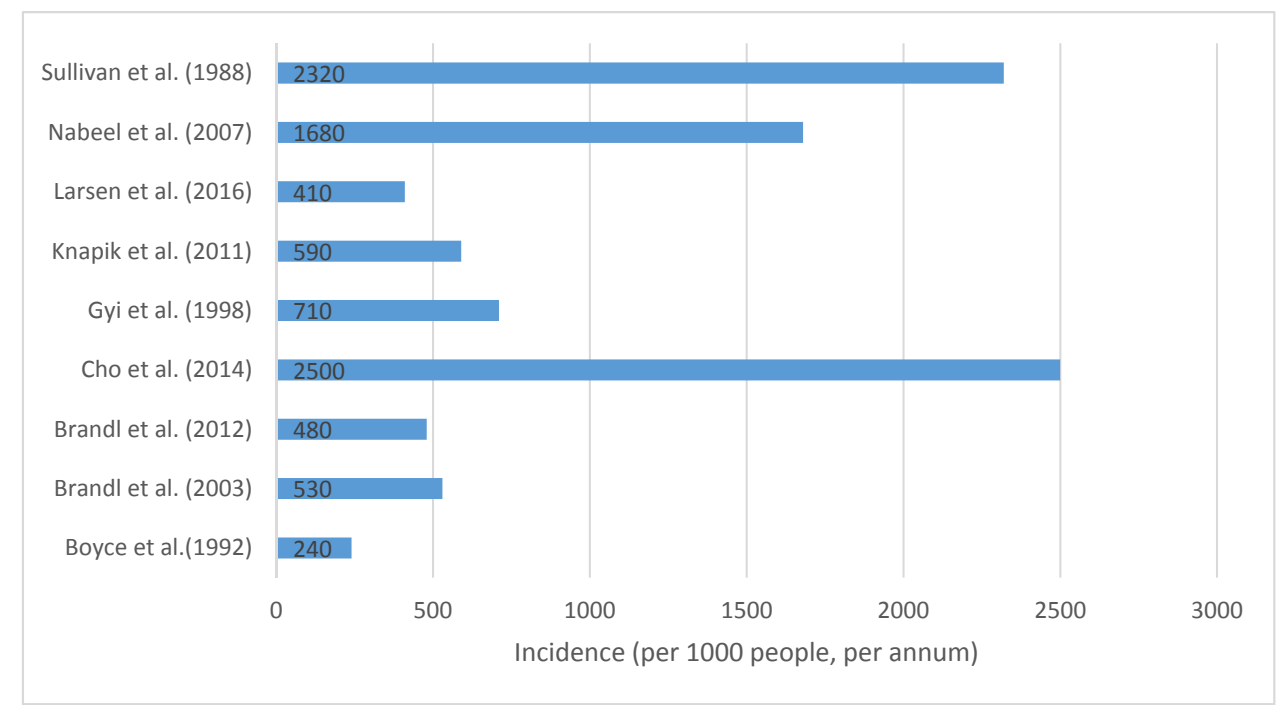

Figure 2. Injury incidence rates, by study (injuries per 1000 personnel per annum). Injury incidence rates are reported here only for studies which provided the required data to make these rates calculable. Studies not included in this figure did not supply adequate data for these calculations.

Five of the included studies $[5,6,13,19,22]$ reported the body sites affected by recorded injuries. Of these, four studies $[5,6,13,19]$ found that the most common site of injury was the upper extremity, with reported proportions of injuries that affected the upper limb ranging from $32.95 \%$ [5] to $43.42 \%$ [13]. The remaining study [22] reported the body site affected by $63.41 \%$ of injuries as 'other (site not specified)', indicating a lack of available detail in the data source, and also reported that a further $20.49 \%$ of injuries recorded in that study affected the back and torso. All five studies $[6,12,18,19,21]$ that investigated the natures of the reported injuries agreed that sprains and strains were the most common nature of injury, with proportions of injuries these represented ranging from $42.36 \%$ [18] to $94.59 \%$ [6]. Of the seven studies $[5,6,12,18,19,21,22]$ that examined how recorded injuries occurred, four $[6,18,19,21]$ reported non-compliant offenders and associated assaults to be the most common cause, accounting for $31.5 \%$ [6] to $61.67 \%$ [21] of recorded injuries. Other, unspecified causes of injury, accounting for between $30 \%$ [22] and $41.7 \%$ [5] of recorded injuries, were reported by two studies [5,22], with the remaining study [12] reporting that $64.16 \%$ of recorded injuries occurred as a result of operational training. 
There were only four studies $[12,16,17,20]$ that discussed risk factors for injury within their results. One study [17] reported a link between increased body fat percentage and increased injury risk but did not provide any statistical data to support this. Another study [20] found that having a body mass index (BMI) greater than $35 \mathrm{~kg} / \mathrm{m}^{2}$ tripled the likelihood of an officer having had back pain in the last 12 months, when compared to those with a BMI less than $35 \mathrm{~kg} / \mathrm{m}^{2}$. Conversely, a third study [12] reported that physical characteristics such as BMI were poorly correlated with injury risk, but did not report any statistical data to support this assertion. A single study [16] investigated the association between lower back conditions and use of body armor, and found that those who wore body armor had a $9 \%$ higher rate of absenteeism due to lower back concerns than those who did not wear the body armor, though the statistical significance of this finding was not reported.

\section{Discussion}

The aim of this review was to identify and critically appraise recently published studies investigating musculoskeletal injuries in the law enforcement profession and then synthesise and report their findings. Many of the included studies not only investigated musculoskeletal injuries but other injuries as well, in these cases the musculoskeletal injury data were extracted and used within this review. With this in mind, it should be stated up front that, overall, the methodological quality of the eligible studies was only 'poor', with a mean $( \pm$ SD) CAS of $41.25 \%( \pm 10.08 \%)$. This relatively low score is in large part due to the majority of the study designs employed being susceptible to bias $[35,36]$. In particular, cross-sectional studies, including studies involving data collection at a single point in time using questionnaires, and retrospective study designs can introduce recall bias and difficulty in collecting complete data sets, and therefore often report lower injury incidence rates $[23,36,37]$. Thus, the findings of this review in relation to injury incidence rates are likely to be conservative and actual injury incidence rates are likely to be higher.

The main findings of this critical review formed five main categories of results for discussion. These were: (1) musculoskeletal injury incidence in law enforcement populations; (2) commonly injured body sites; (3) common natures of injury; (4) common mechanisms of injury (MOI); and (5) factors that may increase the risk of injury.

\subsection{Musculoskeletal Injury Incidence}

The reported incidence of injuries among law enforcement personnel varied from 240 [4] to 2500 [13] per 1000 personnel per annum, across the included studies. Variance in the reported injury incidence rates between studies could in many instances be attributable to research design factors like the included injury types, natures of the studies being compared, sources of data and injury definitions employed [38]. They could also be due to actual differences in injury rates, associated with differences in exposure to occupational tasks and risks and to differences in the levels of cohort resistance to injury, the latter resulting for example from enhanced levels of physical conditioning, from use of personal protective equipment, from development of specialized skill sets or from use of particular coercive tools, including weapons, to subdue offenders. Of the studies which reported injury incidence rates, the only study [4] to gather its data at the point of health care reported the lowest incidence rate. The three studies $[13,20,22]$ with injury incidence rates that exceeded 1000 injuries per 1000 personnel per annum collected their injury data via surveys and workers' compensation claims. Two of these three studies $[13,20]$ collected all of their data via self-report, retrospectively, which relied on the officers' recall ability and their knowledge of their previous injuries. This approach may not be as accurate as data collected at point of care or from a database which stores medical reports [37]. Finally, none of these three studies reported whether the total number of injuries included only the primary injury, or if secondary injuries were also reported and included, and inclusion and separate counting of secondary injuries incurred at the same time as the primary injuries may have artificially elevated reported injury incidence rates. 
Some research has already been completed looking at incidence of injuries amongst other tactical populations (e.g., military, fire fighters) [39-41]. Within the Australian army, incidence rates have been investigated in both full-time and part-time personnel [39]. The incidence rates were reported to be 169.3 and 301.9 per 1000 personnel per year, for full-time and part-time personnel respectively. Though these injury incidence rates are on the lower end of the findings of this review, musculoskeletal under-reporting of injuries is common in military populations, with observed injury under-reporting rates of up to $49 \%$ [42], and so these reported military injury incidence rates may be conservative for that population. In an Australian fire fighter population, retrospective data covering a nine year period was analyzed to determine an injury profile for this population [41]. Injury incidence rates from that study were reported to average 177 injuries per 1000 full-time employees per annum, which is a lower incidence rate than the rates reported in any of the studies included in this review, for law enforcement personnel. Similarly another study completed on firefighters in the United States also found the average annual incidence rate to be 177 (range of 136-215) injuries per 1000 personnel per annum [40]. That study was a descriptive study which analyzed data from fire department injury reports and annual summaries derived from injury surveillance databases. The observed differences in reported injury incidence rates among different tactical populations may be attributed to varying injury definitions, differences in data collection procedures and databases, and differences between the populations and their risk profiles and capacities to resist injury, as discussed above to explain differences between studies included in the current review. The varying natures of occupational tasks within different tactical fields (law enforcement vs. military vs. fire fighter) may also contribute to observed differences in reported injury incidence rates.

\subsection{Affected/Injured Body Site}

The most common body sites affected by injuries in law enforcement personnel were also reported differently across the included studies. For example, some studies reported 'wrist/hand' and 'shoulder' $[6,13,19]$ while others $[5,22]$ listed the site of injury more generally as 'upper extremity'. When considered in broader categories, the most common sites of injury were the upper extremity, 'other unspecified sites', and the torso or back. Of the five included studies that investigated the reported sites of injuries, four $[5,6,13,19]$ reported the upper extremity to be the most common site, representing $32.95 \%$ [5] to $43.42 \%$ [13] of all reported musculoskeletal injuries. The remaining study [22] reported 'other sites' to be the most common site of injury (63.41\%). In this study, 'other sites' was not defined and it is therefore difficult to determine whether some of these injuries were perhaps not musculoskeletal injuries at all.

Other tactical populations, such as the military, have reported the lower limb and back to be the most common sites of injury [43-48]. In fire fighters, the most common sites of injury have similarly been reported to be the lower limb and the back rather than the upper extremity [40,41]. Differences in the most common sites of injury among tactical populations may be attributed to differences in injury definitions and in ways sites are reported and classified, and to how injury data was collected and the nature and focus of the study that was completed. In addition, a further notable contribution to site variations across tactical populations may be differences in occupational tasks, with load carriage requirements serving as an example, since different tactical populations carry different loads weights and configurations in different contexts.

\subsection{Nature of Injury}

This review found the most common natures of injury to be reported by law enforcement personnel were sprains and strains, followed by other muscle pains and other natures of injury. All of the included studies that reported the natures of injuries sustained $[6,12,18,19,21]$ found that sprains and strains were the leading natures of injury, however the reported percentages of all injuries that these natures accounted for varied from $42.36 \%$ [18] to $94.59 \%$ [6]. Unfortunately, the nature of injuries listed as 'other muscle pain' or 'other' was not further elucidated in the included studies. 
The wide variance across the included studies in the percentages of injuries with particular natures may again be explained by differences in study designs, methodological quality and data collection methods, as well as by risk profiles of each population and factors that counter those risks.

There have been similar findings in other tactical populations. In the military context, similar findings have been reported, with ankle and knee sprains representing $51 \%$ of reported injuries in one epidemiological study [49] completed on lower limb injuries occurring within New Zealand Defence Force personnel. Other studies have reported sprains and strains to be the most common natures of injury within military populations but have failed to report proportions of injuries these natures of injury represent $[38,46]$. Fire-fighting has been associated with a similar pattern, with the proportions of injuries that are sprains, strains and dislocations reported to be $40.2 \%-85.2 \%$ [40]. However, in this same population, other reported natures of injuries have included those of a non-musculoskeletal nature (e.g., thermal stress/heat exhaustion, chemical exposure, etc. $[40,41,50])$.

\subsection{Mechanism of Injury}

The most common mechanism of injury reported by four of the seven included studies which examined mechanisms of injury in law enforcement personnel $[6,18,19,21]$ was non-compliant offenders/assault, with percentages of injuries reported to arise from this mechanism varying from $31.5 \%$ [6] to $61.67 \%$ [21]. 'Other unspecified causes' were reported to be the most common mechanism of injury by a further two of the seven included studies [5,22] that examined mechanisms of injury, with reported percentages of injuries attributable to this mechanism in the range of $30 \%$ [22] to $41.71 \%$ [5]. Operational training was reported to be the most common mechanism of injury the final included study [12] that examined mechanisms of injury, associated with $64.16 \%$ of all reported injuries in that study. Like the other characteristics of injuries discussed so far (i.e., site and nature of injuries), the reporting of mechanisms of injury varied between studies. The differences between studies may be due to differences in methodological quality, study design and study aim, as well as to the way in which the data was collected and coded.

In contrast to the studies of law enforcement personnel, within the Australian Regular Army, $31.6 \%$ of injuries were attributed to the muscular stress associated with lifting, carrying or donning of equipment. The two most commonly reported activities within which injury occurred for these army personnel were physical training and operational training [51]. In fire fighters, it was found that no single mechanism of injury could explain more than $20 \%$ of injuries, and the most commonly reported mechanism was muscular stress, which accounted for $15.6 \%$ of reported injuries [41]. Differences in mechanisms of injury between tactical populations may be explained by differences in occupational demands. For example, military personnel are more likely to be carrying notably heavier loads [43], fire fighters are more likely to encounter hazardous environments [41], and law enforcement officers may be more likely to encounter non-compliant offenders $[18,21]$. Other than the differences in occupational demands, observed variations in reported mechanisms of injury across tactical fields may also be due to the study designs and methodological quality, or perhaps how data was collected (e.g., point-of-care versus self-reported methods of data collection).

\subsection{Risk Factors for Injury}

Potential risk factors for injury in law enforcement personnel were identified in this review but, as outlined in results, the findings were inconclusive. A few studies $[12,17,20]$ investigated the link between increased BMI or increased body fat percentage and injury risk, with conflicting findings. One study [17] found a link between increased body fat percentage and increased injury risk, while another study [20] found that a BMI of more than $35 \mathrm{~kg} / \mathrm{m}^{2}$ increased the likelihood of an officer having had back pain. Conversely, a third study [12] reported that physical characteristics such as BMI had little correlation with injury risk. One study [16] also looked at whether wearing body armor had an impact on lower back problems and found there was a correlation between days off due to back problems and wearing body armor. In a government report completed in the United States it was 
found that the proportion of law enforcement officers wearing bullet proof vests or body armor has been increasing [52]. As such, as more officers opt to wear body armor, the risk of back injury can be anticipated to increase.

In the military, there have been associations found between higher injury frequency and increasing age, hypo or hyper mobility, lower fitness levels and previous ankle sprains [46]. No correlation was found between increased body fat percentage or BMI and injury risk in one study [46], while another reported a $47 \%$ increase in musculoskeletal injury risk in army personnel who were overweight or obese [53]. In a fire-fighting population, a BMI of more than $30 \mathrm{~kg} / \mathrm{m}^{2}$ has been shown to increase risk of musculoskeletal injury by 5.2 times [54]. Conversely, another study in this population [50] reported that body composition had no correlation with injury risk. As within law enforcement populations, there is mixed evidence for military and fire-fighting populations relating to whether body composition affects injury risk.

\subsection{Limitations and Future Research}

There were four key limitations in this review: (1) the modal methodological quality of included studies was only 'fair' and there was wide variance in the study designs across the included studies. Due to the methodological quality of the studies included in this review it is difficult to draw conclusive findings based upon their results. The majority of the included studies were retrospective in design and were either cross-sectional or cohort studies, and this combination of design features meant that there was an increased risk of bias [35,36] associated with the study findings; (2) each study reported different variables and the way in which they reported these varied; and due to differences in the injury classifications used across the included studies, broader categories had to be created to be enable valid comparison of results and as such some sensitivity was lost; (3) in the reported results, often there was no description or explanation of what the commonly-used 'other' category comprised; (4) the majority of the included studies had a male only sample, those which did include females were of a relatively low sample size. This limits the ability to be able to provide a gender analysis, and as such future research to investigate and profile gender specific injury may be of benefit to the volume of evidence available.

Future research in this area needs to be conducted with better methodological quality. Larger, prospective cohort studies are needed, so that the results can be applied across the target population. Future studies should adopt a common injury definition and classification system, both of which remain to be developed for tactical populations, so that their findings can be compared with findings from other studies.

\section{Conclusions}

In conclusion, this review found that the current research literature surrounding musculoskeletal injuries affecting law enforcement personnel is limited in volume and of poor methodological quality. The reported incidence of injuries for law enforcement personnel varied from 240 to 2500 injuries per 1000 personnel per year and the most common site of injury was the upper extremity. Reported injuries were commonly sprains or strains caused by a non-compliant offender/assault. Caution is advised in extrapolating these findings to the wider law enforcement population due to the identified concerns regarding methodological quality and variability of reporting in the included studies.

Acknowledgments: No funding was provided for this research project.

Author Contributions: Kate Lyons and Cameron Radburn performed the systematic search of the literature, critical appraisal analysis, and data extraction, analyzed the data and synthesized the findings, and drafted the manuscript. Robin Orr conceived the critical review topic; conducted the Kappa analysis; and reviewed the manuscript. Rodney Pope aided in the development of the search terms and strategies as well as the process of data extraction and reviewed and edited the final manuscript.

Conflicts of Interest: The authors declare no conflict of interest. 


\section{Appendix A}

Table A1. Downs and Black [24] Critical Appraisal results for all included studies.

\begin{tabular}{|c|c|c|c|c|c|c|c|c|c|c|c|c|c|c|c|c|c|c|c|c|c|c|c|c|c|c|c|c|}
\hline \multirow{2}{*}{ Study $(n=16)$} & \multicolumn{28}{|c|}{ Scores Assigned, by Item Number from the Downs and Black Checklist * } \\
\hline & 1 & 2 & 3 & 4 & 5 & 6 & 7 & 8 & 9 & 10 & 11 & 12 & 13 & 14 & 15 & 16 & 17 & 18 & 19 & 20 & 21 & 22 & 23 & 24 & 25 & 26 & 27 & Raw Score \\
\hline Knapik et al., (2011) [12] & 1 & 1 & 1 & & 0 & 1 & 1 & & 1 & 1 & 1 & 1 & & & & 1 & 0 & 1 & & 1 & 0 & 0 & & & 0 & 1 & 0 & $13 / 20$ \\
\hline Violanti et al., (2013) [7] & 1 & 1 & 1 & & 0 & 1 & 1 & & 0 & 1 & 1 & 1 & & & & 0 & 0 & 1 & & 1 & 0 & 0 & & & 0 & 0 & 0 & $10 / 20$ \\
\hline Cho et al., (2014) [13] & 1 & 1 & 1 & & 0 & 1 & 1 & & 1 & 1 & 1 & 0 & & & & 0 & 0 & 1 & & 1 & 0 & 0 & & & 0 & 0 & 0 & $10 / 20$ \\
\hline Boyce et al., (1992) [4] & 1 & 1 & 1 & & 0 & 1 & 1 & & 0 & 1 & 1 & 1 & & & & 0 & 0 & 1 & & 1 & 0 & 0 & & & 0 & 0 & 0 & $10 / 20$ \\
\hline Superko et al., (1988) [17] & 1 & 1 & 0 & & 0 & 1 & 1 & & 0 & 0 & 1 & 0 & & & & 0 & 1 & 1 & & 1 & 1 & 0 & & & 0 & 0 & 0 & $9 / 20$ \\
\hline Gyi et al., (1998) [15] & 1 & 0 & 1 & & 1 & 1 & 1 & & 0 & 0 & 1 & 0 & & & & 0 & 0 & 1 & & 1 & 0 & 1 & & & 0 & 0 & 0 & $9 / 20$ \\
\hline Burton et al., (1996) [16] & 1 & 1 & 1 & & 0 & 1 & 1 & & 0 & 0 & 1 & 1 & & & & 0 & 0 & 1 & & 1 & 0 & 0 & & & 0 & 0 & 0 & $9 / 20$ \\
\hline Sullivan et al., (1988) [22] & 1 & 1 & 1 & & 0 & 1 & 1 & & 0 & 0 & 1 & 0 & & & & 1 & 0 & 1 & & 1 & 0 & 0 & & & 0 & 0 & 0 & $9 / 20$ \\
\hline Jahani et al., (2002) [11] & 1 & 1 & 1 & & 0 & 1 & 1 & & 0 & 0 & 1 & 0 & & & & 0 & 0 & 1 & & 1 & 0 & 0 & & & 0 & 0 & 0 & $8 / 20$ \\
\hline Holloway-Beth et al., (2016) [5] & 1 & 1 & 1 & & 0 & 1 & 1 & & 0 & 1 & 0 & 0 & & & & 0 & 0 & 1 & & 1 & 0 & 0 & & & 0 & 0 & 0 & $8 / 20$ \\
\hline Nabeel et al., (2007) [20] & 1 & 1 & 0 & & 0 & 1 & 1 & & 0 & 1 & 0 & 0 & & & & 0 & 0 & 1 & & 1 & 0 & 0 & & & 0 & 0 & 0 & $7 / 20$ \\
\hline Reichard et al., (2010) [19] & 1 & 1 & 0 & & 0 & 1 & 1 & & 0 & 0 & 1 & 0 & & & & 0 & 0 & 1 & & 1 & 0 & 0 & & & 0 & 0 & 0 & $7 / 20$ \\
\hline Brandl et al., (2012) [18] & 1 & 1 & 0 & & 0 & 1 & 0 & & 0 & 0 & 1 & 1 & & & & 0 & 0 & 1 & & 1 & 0 & 0 & & & 0 & 0 & 0 & $7 / 20$ \\
\hline Brandl et al., (2003) [21] & 1 & 1 & 0 & & 0 & 1 & 0 & & 0 & 0 & 1 & 1 & & & & 0 & 0 & 0 & & 1 & 0 & 0 & & & 0 & 0 & 0 & $6 / 20$ \\
\hline Larsen et al., (2016) [6] & 1 & 1 & 0 & & 0 & 1 & 0 & & 0 & 0 & 1 & 0 & & & & 0 & 0 & 0 & & 1 & 0 & 0 & & & 0 & 0 & 0 & $5 / 20$ \\
\hline Rhee et al., (2015) [14] & 1 & 1 & 0 & & 0 & 1 & 0 & & 0 & 0 & 1 & 0 & & & & 0 & 0 & 0 & & 1 & 0 & 0 & & & 0 & 0 & 0 & $5 / 20$ \\
\hline
\end{tabular}

${ }^{*}$ Questions from the checklist that were ignored as planned due to lack of relevance to the research designs of the included studies are left blank. 


\section{References}

1. Bonneau, J.; Brown, J. Physical ability, fitness and police work. J. Clin. For. Med. 1995, 2, 157-164. [CrossRef]

2. Pryor, R.R.; Colburn, D.; Crill, M.T.; Hostler, D.P.; Suyama, J. Fitness Characteristics of a Suburban Special Weapons and Tactics Team. J. Strength Cond. Res. 2012, 26, 752-757. [CrossRef] [PubMed]

3. Achterstraat, P. Managing Injured Police: NSW Police Force; Auditor-General, Ed.; Audit Office of New South Wales: Sydney, Australia, 2008.

4. Boyce, R.W.; Hiatt, A.R.; Jones, G.R. Workers' compensation claims and physical fitness capacity of police officers. Health Values J. Health Behav. Educ. Promot. 1992, 16, 22-29.

5. Holloway-Beth, A.; Forst, L.; Freels, S.; Brandt-Rauf, S.; Friedman, L. Occupational Injury Surveillance Among Law Enforcement Officers Using Workers' Compensation Data, Illinois 1980 to 2008. J. Occup. Environ. Med. 2016, 58, 594-600. [CrossRef] [PubMed]

6. Larsen, B.; Aisbett, B.; Silk, A. The Injury Profile of an Australian Specialist Policing Unit. Int. J. Environ. Res. Public Health 2016, 13, 370. [CrossRef] [PubMed]

7. Violanti, J.M.; Fekedulegn, D.; Andrew, M.E.; Charles, L.E.; Hartley, T.A.; Vila, B.; Burchfiel, C.M. Shift work and long-term injury among police officers. Scand. J. Work Environ. Health 2013, 39, 361-368. [CrossRef] [PubMed]

8. Pope, R.P. Prevention of pelvic stress fractures in female army recruits. Mil. Med. 1999, 164, 370-373. [PubMed]

9. Pope, R.P. Injury surveillance and systematic investigation identify a rubber matting hazard for anterior cruciate ligament rupture on an obstacle course. Mil. Med. 2002, 167, 359-362. [PubMed]

10. Drew, M.K.; Cook, J.; Finch, C.F. Sports-related workload and injury risk: Simply knowing the risks will not prevent injuries. Br. J. Sports Med. 2016. [CrossRef] [PubMed]

11. Jahani, M.R.; Motevalian, S.A.; Asgari, A.R. Musculoskeletal disabilities among police force personnel of the Islamic Republic of Iran. Mil. Med. 2002, 167, 850-852. [PubMed]

12. Knapik, J.J.; Grier, T.; Spiess, A.; Swedler, D.I.; Hauret, K.G.; Graham, B.; Yoder, J.; Jones, B.H. Injury rates and injury risk factors among federal bureau of investigation new agent trainees. BMC Public Health 2011, 11, 1-16. [CrossRef] [PubMed]

13. Cho, T.-S.; Jeon, W.-J.; Lee, J.-G.; Seok, J.-M.; Cho, J.-H. Factors Affecting the Musculoskeletal Symptoms of Korean Police Officers. J. Phys. Therapy Sci. 2014, 26, 925-930. [CrossRef] [PubMed]

14. Rhee, H.Y.; Cho, J.H.; Seok, J.M.; Cho, T.S.; Jeon, W.J.; Lee, J.G.; Kim, S.K. Prevalence of Musculoskeletal Disorders Among Korean Police Personnel. Arch. Environ. Occup. Health 2015, 70, 177-188. [CrossRef] [PubMed]

15. Gyi, D.E.; Porter, J.M. Musculoskeletal problems and driving in police officers. Occup. Med. (Oxf. Engl.) 1998, 48, 153-160. [CrossRef]

16. Burton, A.K.; Tillotson, K.M.; Symonds, T.L.; Burke, C.; Mathewson, T. Occupational risk factors for the first-onset and subsequent course of low back trouble: A study of serving police officers. Spine (03622436) 1996, 21, 2612-2620. [CrossRef]

17. Superko, H.R.; Bernauer, E.; Voss, J. Effects of a Mandatory Health Screening and Physical Maintenance Program for Law Enforcement Officers. Phys. Sportsmed. 1988, 16, 99-109. [CrossRef] [PubMed]

18. Brandl, S.G.; Stroshine, M.S. The Physical Hazards of Police Work Revisited. Police Quart. 2012, 15, $262-282$. [CrossRef]

19. Reichard, A.A.; Jackson, L.L. Occupational injuries among emergency responders. Am. J. Ind. Med. 2010, 53, 1-11. [CrossRef] [PubMed]

20. Nabeel, I.; Baker, B.A.; McGrail, M.P., Jr.; Flottemesch, T.J. Correlation between physical activity, fitness, and musculoskeletal injuries in police officers. Minn. Med. 2007, 90, 40-43. [PubMed]

21. Brandl, S.G.; Stroshine, M.S. Toward an Understanding of the Physical Hazards of Police Work. Police Quart. 2003, 6, 172-191. [CrossRef]

22. Sullivan, C.S.B.; Shimizu, K.T. Epidemiological studies of work-related injuries among law enforcement personnel. J. Soc. Occup. Med. 1988, 38, 33-40. [CrossRef] [PubMed]

23. Tricco, A.C.; Tetzlaff, J.; Sampson, M.; Fergusson, D.; Cogo, E.; Horsley, T.; Moher, D. Few systematic reviews exist documenting the extent of bias: A systematic review. J. Clin. Epidemiol. 2008, 61, 422-434. [CrossRef] [PubMed] 
24. Downs, S.H.; Black, N. The feasibility of creating a checklist for the assessment of the methodological quality both of randomised and non-randomised studies of health care interventions. J. Epidemiol. Community Health 1998, 52, 377-384. [CrossRef] [PubMed]

25. Eng, J.J.; Teasell, R.; Miller, W.C.; Wolfe, D.L.; Townson, A.F.; Aubut, J.A.; Abramson, C.; Hsieh, J.T.; Connolly, S.; Konnyu, K. Spinal Cord Injury Rehabilitation Evidence: Methods of the SCIRE Systematic Review. Top. Spinal Cord. Inj. Rehabil. 2007, 13, 1-10. [CrossRef] [PubMed]

26. Carlton, S.D.; Orr, R.M. The impact of occupational load carriage on carrier mobility: A critical review of the literature. Int. J. Occup. Saf. Ergon. 2014, 20, 33-41. [CrossRef] [PubMed]

27. Cocke, C.; Orr, R. The impact of physical training programs on the fitness of tactical populations: A critical review. J. Strength Cond. 2015, 23, 39-46.

28. MacDonald, D.; Pope, R.; Orr, R. Differences in physical characteristics and performance measures of part-time and full-time tactical personnel: A critical narrative review. J. Mil. Vet. Health 2016, 24, 45-55.

29. Walker, A.; Pope, R.; Orr, R.M. The impact of fire suppression tasks on firefighter hydration: A critical review with consideration of the utility of reported hydration measures. Ann. Occup. Environ. Med. 2016, 28, 63. [CrossRef] [PubMed]

30. Viera, A.J.; Garrett, J.M. Understanding interobserver agreement: The kappa statistic. Fam. Med. 2005, 37, 360-363. [PubMed]

31. Kennelly, J. Reducing Racial/Ethnic Disparities in Reproductive and Perinatal Outcomes, 1st ed.; Springer: New York, NY, USA, 2011.

32. NHMRC, NHMRC Additional Levels of Evidence and Grades for Recommendations for Developers of Guidelines. Australian Government NHMRC: Canberra, 2009. Available online: https://www.nhmrc. gov.au/files_nhmrc/file/guidelines/developers/nhmrc_levels_grades_evidence_120423.pdf (accessed on 14 December 2016).

33. Moher, D.; Liberati, A.; Tetzlaff, J.; Altman, D.G.; Group, P. Preferred reporting items for systematic reviews and meta-analyses: The PRISMA statement. Int. J. Surg. 2010, 8, 336-341. [CrossRef] [PubMed]

34. Orr, R.M.; Johnston, V.; Coyle, J.; Pope, R. Reported load carriage injuries of the Australian army soldier. J. Occup. Rehabil. 2015, 25, 316-322. [CrossRef] [PubMed]

35. Tacconelli, E. Systematic reviews: CRD's guidance for undertaking reviews in health care. Lancet Infect. Dis. 2010, 10, 226. [CrossRef]

36. Thiese, M.S. Observational and interventional study design types; an overview. Biochem. Med. 2014, 24, 199-210. [CrossRef] [PubMed]

37. Junge, A.; Dvorak, J. Influence of Definition and Data Collection on the Incidence of Injuries in Football. Am. J. Sports Med. 2000, 28 (Suppl. 5), S40-S46. [CrossRef] [PubMed]

38. Andersen, K.A.; Grimshaw, P.N.; Kelso, R.M.; Bentley, D.J. Musculoskeletal Lower Limb Injury Risk in Army Populations. Sports Med. Open 2016, 2, 22. [CrossRef] [PubMed]

39. Pope, R.; MacDonald, D.; Orr, R. Incidence Rates of Reported Work Health \& Safety Incidents E Injuries in Parttime $\mathcal{E}$ Full-Time Australian Army Personnel; Bond Institute of Health and Sport: Robina, Australia, 2017.

40. Poplin, G.S.; Harris, R.B.; Pollack, K.M.; Peate, W.F.; Burgess, J.L. Beyond the fireground: Injuries in the fire service. Inj. Prev. 2012, 18, 228-233. [CrossRef] [PubMed]

41. Taylor, N.A.S.; Dodd, M.J.; Taylor, E.A.; Donohoe, A.M. A Retrospective Evaluation of Injuries to Australian Urban Firefighters (2003 to 2012): Injury Types, Locations, and Causal Mechanisms. J. Occup. Environ. Med. 2015, 57, 757-764. [CrossRef] [PubMed]

42. Smith, L.; Westrick, R.; Sauers, S.; Cooper, A.; Scofield, D.; Claro, P.; Warr, B. Underreporting of Musculoskeletal Injuries in the US Army: Findings From an Infantry Brigade Combat Team Survey Study. Sports Health 2016, 8, 507-513. [CrossRef] [PubMed]

43. Orr, R.M.; Pope, R.; Johnston, V.; Coyle, J. Soldier occupational load carriage: A narrative review of associated injuries. Int. J. Inj. Control Saf. Promot. 2014, 21, 388-396. [CrossRef] [PubMed]

44. Feuerstein, M.; Berkowitz, S.M.; Peck, C.A., Jr. Musculoskeletal-related disability in US Army personnel: Prevalence, gender, and military occupational specialties. J. Occup. Environ. Med. 1997, 39, 68-78. [CrossRef] [PubMed]

45. Hauret, K.G.; Jones, B.H.; Bullock, S.H.; Canham-Chervak, M.; Canada, S. Musculoskeletal Injuries. Am. J. Prev. Med. 2010, 38, S61-S70. [CrossRef] [PubMed] 
46. Jones, B.H.; Cowan, D.N.; Tomlinson, J.P.; Robinson, J.R.; Polly, D.W.; Frykman, P.N. Epidemiology of injuries associated with physical training among young men in the army. Med. Sci. Sports Exerc. 1993, 25, 197-203. [CrossRef] [PubMed]

47. Knapik, J.; Ang, P.; Reynolds, K.; Jones, B. Physical Fitness, Age, and Injury Incidence in Infantry Soldiers. J. Occup. Environ. Med 1993, 35, 598-603. [CrossRef]

48. Rauh, M.J.; Macera, C.A.; Trone, D.W.; Shaffer, R.A.; Brodine, S.K. Epidemiology of stress fracture and lower-extremity overuse injury in female recruits. Med. Sci. Sports Exerc. 2006, 38, 1571-1577. [CrossRef] [PubMed]

49. Davidson, P.L.; Chalmers, D.J.; Wilson, B.D.; McBride, D. Lower limb injuries in New Zealand Defence Force personnel: Descriptive epidemiology. Aust. N. Z. J. Public Health 2008, 32, 167-173. [CrossRef] [PubMed]

50. Jahnke, S.A.; Poston, W.S.C.; Haddock, C.K.; Jitnarin, N. Injury among a population based sample of career firefighters in the central USA. Inj. Prev. 2013, 19, 393-398. [CrossRef] [PubMed]

51. MacDonald, D.; Pope, R.; Orr, R. Profiling the Incidents and Injuries of Part-Time and Full-Time Soldiers in the Australian Army; Bond Institute of Health and Sport: Robina, Australia, 2017.

52. James, N. Body Armor for Law Enforcement Officers; Policy, C., Ed.; Congressional Research Service: Washington, DC, USA, 2016.

53. Cowan, D.N.; Bedno, S.A.; Urban, N.; Yi, B.; Niebuhr, D.W. Musculoskeletal injuries among overweight army trainees: Incidence and health care utilization. Occup. Med. 2011, 61, 247-252. [CrossRef] [PubMed]

54. Jahnke, S.A.; Poston, W.S.C.; Haddock, C.K.; Jitnarin, N. Obesity and incident injury among career firefighters in the central United States. Obesity 2013, 21, 1505-1508. [CrossRef] [PubMed]

(C) 2017 by the authors; licensee MDPI, Basel, Switzerland. This article is an open access article distributed under the terms and conditions of the Creative Commons Attribution (CC BY) license (http:/ / creativecommons.org/licenses/by/4.0/). 